\title{
PENINGKATAN KECERDASAN INTRAPERSONAL DAN KECERDASAN INTERPERSONAL MELALUI METODE BERMAIN PERAN DI KELOMPOK B PAUD TITIAN KASIH
}

\author{
Radjiman Ismail ${ }^{1}$, Nurfitri Sahidun ${ }^{2}$ \\ 1,2 Institut Agama Islam Negeri (IAIN) Ternate \\ e-mail: 1radjiman ismail@yahoo.com,2nurfitriperdana@gmail.com,
}

Diterima: 6 November 2019 | Direvisi: 12 Desember 2019 | Disetujui: 13 Desember 2019 (C)2019 Pendidikan Guru Raudhatul Atfhal Fakultas Agama Islam Universitas Islam Malang

\begin{abstract}
The aims of this research to know the increased of children intrapersonal intelligence and interpersonal intelligence through role playing methods. Respondents of the research involved of 20 children from group $B$ at PAUD Titian Kasih. The method of this research consists by Kemmis and Taggart model. The score of data were analyzed by using quantitative and qualitative approach. The results of data indicate that interpersonal intelligence and intrapersonal intelligence of children have increased, based on the first cycle, it can be seen that children's interpersonal intelligence and intrapersonal intelligence have increased by $10.37 \%$, in the pre-test the average the class average was 41.33 or $46.96 \%$ and in the first cycle it became 46 or $57.33 \%$. In the second cycle of interpersonal intelligence and intrapersonal intelligence of children has increased by $22.59 \%$. In the second cycle the children obtained an average score of 64.47 or $79.92 \%$. The conclusions are the score of interpersonal intelligence and intrapersonal intelligence of children increases from pre-research to first cycle and from first cycle to second cycle, the implementation of the role playing method in teaching and learning gives children the opportunity to explore various intelligence possessed by children, especially intelligence interpersonal intelligence and intrapersonal intelligence.
\end{abstract}

Keywords: intrapersonal intelligence, interpersonal intelligence, the role playing method.

\section{A. Pendahuluan}

Setiap anak memiliki berbagai kecerdasan dengan tingkat dan indikator yang berbeda-beda. Dalam teori multiple intellegences, disebutkan ada sembilan kecerdasan yang dimiliki oleh setiap individu, dua diantaranya adalah kecerdasan interpersonal dan kecerdasan intrapersonal. Kedua kecerdasan ini berkaitan dengan kemampuan sosial dan kemampuan memahami diri. Anak yang memiliki kecerdasan interpersonal akan mampu memiliki hubungan sosial yang baik dengan lingkungannya. Perkembangan zaman yang semakin hari semakin canggih

This work is licensed under Creative Commons Attribution Non Commercial 4.0 International License Available online on: http://riset.unisma.ac.id/index.php/fai/index 
menuntut tiap individu untuk ikut terlibat dalam perkembangan tersebut. Manusia semakin dijajah oleh gadget dan hal itu tidak lepas dengan dunia anak. Dengan adanya faktor tersebut yang memiliki pengaruh positif dan negatif serta kurangnya pola asuh yang baik dari orangtua kepada anak maka kemampuan dalam bersosial dan kemampuan dalam memahami diri sendiri semakin menurun. Kegiatankegiatan atau permainan-permainan sosial yang melibatkan kerja sama serta pengembangan diri tidak lagi intens dilaksanakan terutama di lingkungan rumah dan di lingkungan sekolah yang pelajarannya masih seputar baca, tulis dan hitung.

Pemerintah telah mencanangkan bahwa pendidikan anak usia dini bukan hanya semata-mata mengenal baca, tulis dan hitung. Kekeliruan ini masih menjadi momok bagi para guru dan orang tua dalam mendidik anak. Padahal masih banyak jenis kecerdasan yang dapat ditingkatkan melalui lembaga ini. Hal inilah yang mendasari peneliti untuk melakukan perbaikan dengan menawarkan solusi metode bermain peran untuk meningkatan kecerdasan interpersonal dan kecerdasan intrapersonal anak. Kecerdasan interpersonal yang merupakan kemampuan untuk berhubungan dengan orang lain (Suyadi, 2014:133), anak akan mudah bergaul dan sama sekali tidak ada hambatan dalam membina hubungan serta melakukan sosialisasi terutama ketika belajar di kelas. Jelas dalam hal ini, hubungan sosial akan tercipta dengan baik apabila setiap individu memiliki kemampuan dalam membina hubungan dan memahami situasi sosial.

Kecerdasan interpersonal dapat terlihat dengan munculnya kegiatankegiatan (Musfiroh, 2008:56):

(1) Mengajari teman sebaya.

(2) Memiliki perhatian yang besar pada teman sebaya.

(3) Banyak terlibat dalam kegiatan kelompok

(4) Mudah bersosialisasi

(5) Cenderung berbicara dengan teman

(6) Menjawab pertanyaan secara rinci

(7) Lebih fokus

Anak yang memiliki ciri-ciri yang disebutkan diatas, termasuk ke dalam kategori anak yang memiliki kecerdasan interpersonal. Dewasa ini, kita melihat kecerdasan sosial atau kecerdasan interpersonal sudah mulai menurun dikarenakan berbagai faktor. Jika anak dapat memahami orang lain, anak akan dengan mudah menciptakan relasi dalam mempertahankan kehidupan bersosial. Kecerdasan interpersonal dipahami sebagai ketrampilan sesorang dalam memahami dan merespon dengan baik keadaan orang lain (Nurunnisa, 2017:12). Kemampuan dalam berkomunikasi merupakan unsur utama dalam membina hubungan antar sosial. Seseorang dapat menyampaikan maksud dan tujuan serta 
ide-idenya tentu saja hal itu dapat terlaksana melalui komunikasi. Akan tetapi komunikasi perlu dilatih agar komunikasi yang diharapkan adalah komunikasi yang baik. Banyak penelitian telah membuktikan bahwa kecerdasan interpersonal sangat penting dimiliki oleh manusia. Karena individu yang memiliki kecerdasan interpersonal tentu saja dapat membuat hubungan sosial yang positif dan mampu mendukung kesejahteraannya.

Kecerdasan intrapersonal dapat dikategorikan sebagai kecerdasan dalam mengenal dan memahami diri sendiri, melakukan reaksi terhadap situasi dan adanya sikap serta mampu mengintropeksi diri sendiri. Self knowledge and the ability to act adaptively on the basis of the knowledge (Armstrong, 2009:7). Dengan kecerdasan ini, anak mampu berdiri sendiri sehingga tidak mudah bergantung pada orang lain. Dengan kata lain, kecerdasan ini berhubungan dengan bagaimana seseorang merefleksi diri dan dapat berpikir kritis. Kecerdasan intrapersonal yang kuat mampu membawa anak menuju pada kesuksesan. Hal ini disadari karena kesuksesan seseorang tidak hanya diukur dari kemampuan akademik melainkan dari kemampuan seseorang dalam menempatkan diri dan bergaul dengan lingkungan sekitarnya. Kecerdasan intrapersonal adalah kecerdasan kunci (Hoerr, 2007:114). Anak dengan kecerdasan ini dapat memiliki gambaran yang akurat tentang diri sendiri sehingga cenderung menjadi anak yang berpikir kritis yang tercermin pada apa yang anak kerjakan dan terus membuat penilaian terhadap diri sendiri.

Lingkungan belajar pendidikan anak usia dini memiliki peranan yang penting dalam meningkatkan berbagai kecerdasan atau potensi yang dimiliki anak, terutama dalam peningkatan kecerdasan interpersonal dan kecerdasan intrapersonal. Melalui lingkungan dalam hal ini adalah sekolah, anak memulai interaksi dengan teman dan guru. Proses interaksi ini tidak boleh luput dari perhatian, dikarenakan banyak aspek perkembangan yang dapat terlihat bahkan hal-hal kecil sekalipun. Peranan guru dalam memilih metode pembelajaran yang tepat juga bukan sekedar saja. Metode yang tepat untuk peningkatan kemampuan dan kegiatan bermain yang menyenangkan merupakan kunci utama dalam pembelajaran di kelas PAUD. Hasil observasi yang penulis temukan di lembaga PAUD Titian Kasih adalah masih relatif monoton pembelajaran yang dilakukan. Guru belum memahami bahwa kecerdasan sosial dan kecerdasan dalam pemahaman diri itu penting. Sehingga, pembelajaran di kelas hanya berfokus pad abaca, tulis dan hitung saja.

Dalam pemilihan metode pembelajaran untuk anak usia dini dibutuhkan berbagai pertimbangan, salah satunya yaitu metode harus dapat menyenangkan agar anak tidak bosan dan jenuh ketika kegiatan berlangsung. Seyogyanya, anak 
usia dini senang akan bermain khayalan. Anak suka meniru apa yang ada dan apa yang terjadi di sekitar lingkungan anak. Bermain peran adalah praktik yang dilakukan anak dalam kegiatan kehidupan nyata. Hal ini memberikan kesempatan kepada anak untuk membayangkan dirinya ke dalam masa depan dan menciptakan kembali kondisi masa lalu. Kegiatan bermain peran dapat mendukung perkembangan anak secara keseluruhan. Keterlibatan anak dalam bermain peran dapat memberikan banyak manfaat untuk peningkatan berbagai kecerdasan anak.

\section{B. Metode}

Jenis penelitian ini adalah Penelitian Tindakan Kelas (PTK). Penelitian tindakan ini menggunakan acuan yang digunakan dalam penelitian Classroom Action Research model Kemmis dan Taggart dan dilaksanakan melalui dua siklus yang meliputi empat tahapan yang meliputi planning (perencanaan), action (tindakan), observation (observasi), reflection (refleksi) serta revition (revisi), perencanaan ulang sebagai pemecah masalah (Arikunto, 2006).

\section{Gambar 1. Model Tindakan yang dilakukan}

1. Mengamati perubahan yang terjadi pada anak saat dan setelah dilaksanakan kegiatan bermain peran.

2. Mengadakan pertemuan untuk membahas hasil tindakan pembiasaan

3. Evaluasi tindakan I

1. Melakukan observasi terhadap kecerdasan interpersonal dan intrapersonal anak dengan menggunakan format observasi

2. Mengamati kegiatan bermain peran anak yang dilakukan secara langsung antara peneliti dan obyek

3. Mengevaluasi metode.

1. Mengamati perubahan yang terjadi pada anak setelah dilakukannya tindakan II

2. Evaluasi tindakan II.
Observasi awal kecerdasan interpersonal dan intrapersonal anak dengan menggunakan format observasi

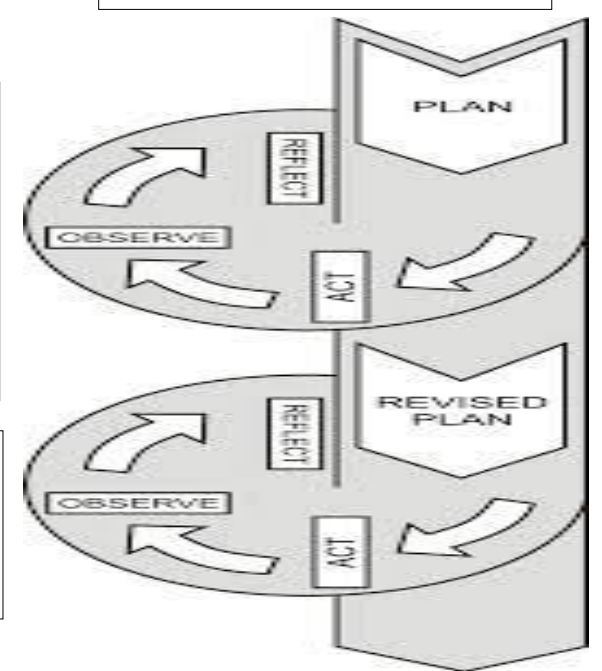

1. Analisis pengembangan fokus-fokus selama di PAUD Titian Kasih.

2. Mempersiapkan media-media yang digunakan selama kegiatan bermain peran.

1. Melaksanakan kegiatan bermain peran berdasarkan perencanaan

2. Melakukan pengamatan isi tindakan

3. Mengumpulkan data pelengkap lainnya yang mendukung terjadinya peningkatan kecerdasan intrapersonal dan kecerdasan interpersonal.

Merevisi pembelajaran sesuai dengan hasil siklus I

1. Mengamati kegiatan pembelajaran sesuai dengan siklus perencanaan II

2. Pengumpulan data tindakan II.

Pengaplikasian pembelajaran sesuai dengan rencana siklus I. 
Penelitian ini dilaksanakan di PAUD Titian Kasih Kelompok B yang beralamat di Jalan Rekreasi Pantai Kastela, Kecamatan Pulau Ternate, Provinsi Maluku Utara. Subjek penelitian terdiri dari siswa Kelompok B PAUD Titian Kasih yang terdiri dari 11 perempuan dan 9 laki-laki. Instrumen yang digunakan oleh peneliti dalam meningkatkan kecerdasan interpersonal dan kecerdasan intrapersonal melalui metode bermain peran adalah lembar observasi untuk siswa dan lembar pertanyaan wawancara untuk siswa, guru dan kepala sekolah. Adapun aspek dan indikator hasil yang diharapkan berdasarkan kecerdasan interpersonal dan kecerdasan intrapersonal anak.

Tekhnik pengumpulan data yang dilakukan peneliti adalah melalui observasi, wawancara dan dokumentasi serta pengumpulan data berdasarkan instrumen penelitian. Sedangkan untuk analisis data dilakukan dengan pendekatan kualitatif dan kuantitatif.

\section{Hasil dan Pembahasan}

Peneliti melakukan kolaborasi dengan guru untuk melakukan asesmen perkembangan kecerdasan intrapersonal dan kecerdasan interpersonal anak pada pra penelitian dalam rangka mengetahui kondisi awal kecerdasan intrapersonal dan kecerdasan interpersonal anak. Kegiatan pra penelitian ini melibatkan 20 orang anak pada kelompok B. Data pretest diperoleh dengan melakukan asesmen perkembangan yang disusun dalam intrumen kecerdasan intrapersonal dan kecerdasan interpersonal anak pada anak 5-6 tahun yang terdiri dari 8 butir pernyataan untuk kecerdasan interpersonal dan 8 butir pernyataan untuk kecerdasan intrapersonal.

Skor kecerdasan intrapersonal dan kecerdasan interpersonal anak dibagi menjadi empat tingkatan pencapaian dengan klasifikasi sebagai berikut:

Tabel 1. Konversi Skor Kecerdasan Intrapersonal dan Kecerdasan Interpersonal Anak

\begin{tabular}{|c|c|c|}
\hline Rentangan Skor & Skor & Keterangan \\
\hline $8,0-28,0$ & 1 & Belum Berkembang \\
\hline $28,1-48,2$ & 2 & Mulai Berkembang \\
\hline $48,3-68,3$ & 3 & Berkembang Sesuai Harapan \\
\hline $68,4-88,4$ & 4 & Berkembang Sangat Baik \\
\hline
\end{tabular}




\section{Deskripsi Data Pre-Test}

Rata-rata skor kecerdasan intrapersonal dan kecerdasan interpersonal anak yang diharapkan dalam hipotesis tindakan penelitian berada pada tahapan berkembang sesuai harapan. Berikut disajikan ke dalam tabel sebagai berikut:

Tabel 2. Data Skor Kecerdasan Interpersonal dan Kecerdasan Intrapersonal Anak Kelompok B Pra Penelitian

\begin{tabular}{|c|c|c|c|c|c|c|}
\hline Responden & $\begin{array}{c}\text { Total Skor } \\
\text { Kecerdasan } \\
\text { Interpersonal }\end{array}$ & Persentase & Ket. & $\begin{array}{c}\text { Total Skor } \\
\text { Kecerdasan } \\
\text { Intrapersonal }\end{array}$ & Persentase & Ket. \\
\hline MF & 38 & $43,18 \%$ & MB & 48 & $54,55 \%$ & MB \\
\hline NU & 48 & $54,55 \%$ & MB & 47 & $53,40 \%$ & MB \\
\hline AJ & 59 & $67,04 \%$ & BSH & 55 & $62,5 \%$ & BSH \\
\hline SS & 47 & $53,40 \%$ & MB & 47 & $53,40 \%$ & MB \\
\hline FJ & 55 & $62,5 \%$ & BSH & 59 & $67,04 \%$ & BSH \\
\hline LS & 47 & $53,40 \%$ & MB & 35 & $39,77 \%$ & MB \\
\hline HS & 47 & $53,40 \%$ & MB & 47 & $53,40 \%$ & MB \\
\hline SH & 34 & $38,63 \%$ & BB & 47 & $53,40 \%$ & MB \\
\hline DA & 28 & $31,81 \%$ & BB & 29 & $32,95 \%$ & BB \\
\hline AL & 29 & $32,95 \%$ & BB & 29 & $32,95 \%$ & BB \\
\hline DS & 35 & $39,77 \%$ & MB & 47 & $53,40 \%$ & MB \\
\hline AY & 29 & $32,95 \%$ & BB & 38 & $43,18 \%$ & MB \\
\hline PI & 34 & $38,63 \%$ & MB & 48 & $54,55 \%$ & MB \\
\hline NK & 47 & $53,40 \%$ & MB & 47 & $53,40 \%$ & MB \\
\hline AA & 47 & $53,40 \%$ & MB & 34 & $38,63 \%$ & MB \\
\hline AI & 55 & $62,5 \%$ & BSH & 59 & $67,04 \%$ & BSH \\
\hline IA & 59 & $67,04 \%$ & BSH & 59 & $67,04 \%$ & BSH \\
\hline IJ & 28 & $31,81 \%$ & BB & 29 & $32,95 \%$ & BB \\
\hline FI & 29 & $32,95 \%$ & BB & 35 & $39,77 \%$ & MB \\
\hline MR & 38 & $43,18 \%$ & MB & 38 & $43,18 \%$ & MB \\
\hline Rata-rata & $\mathbf{4 1 , 6 5}$ & $\mathbf{4 7 , 3 2 \%}$ & MB & $\mathbf{4 3 , 8 5}$ & $\mathbf{4 9 , 8 2 \%}$ & MB \\
\hline Kelas & & & & & & \\
\hline
\end{tabular}

Tabel tersebut menggambarkan bahwa rata-rata skor kecerdasan intrapersonal pada anak kelompok B PAUD Titian Kasih Ternate pada pra penelitian berada pada kategori mulai berkembang dengan presentase 47,32\% dan rata-rata skor kecerdasan interpersonal berada pada kategori mulai berkembang dengan presentase 49,82\%. Sebagai data tambahan, peneliti melakukan wawancara dengan kepala sekolah di PAUD Titian Kasih dan mendapatkan keterangan bahwa guru belum melakukan pembelajaran yang berpusat pada anak dan kurang memberikan kesempatan pada anak untuk bisa mandiri dalam melakukan berbagai aktivitas khususnya bekerja sama dengan kompak, bergaul dengan teman, memahami teman, menerima kritikan dari guru atau teman, dan memiliki cita-cita yang jelas.

Hasil pengamatan awal juga menunjukkan kurang adanya stimulus atau alternatif kegiatan yang dapat meningkatan kecerdasan intrapersonal dan 
kecerdasan interpersonal anak. Guru belum menyadari bahwa kecerdasan interpersonal dan kecerdasan intrapersonal harus dikembangkan pada anak sedini mungkin. Guru kurang memberikan anak motivasi agar mudah bergaul, memahami orang lain, bekerja sama dengan orang lain, mengenal diri sendiri, menerima kritikan dan memiliki cita-cita yang jelas.

\section{Deskripsi Data Siklus I}

Sebelum tindakan pertama dilakukan guru dan peneliti membahas tentang apa saja yang dipersiapkan dalam melakukan metode bermain peran, yakni dalam hal ini peneliti, kolaborator dan kepala sekolah sepakat untuk melakukan metode bermain peran 4 kali pertemuan dalam satu siklus dan 2 kali pertemuan dalam 1 minggu. Guru diberikan kesempatan untuk penyesuaian dalam metode bermain peran, kemudian berdiskusi tentang jenis kegiatan bermain peran yang cocok untuk dikenalkan pada anak usia dini, serta peneliti dan guru bersama-sama menyetujui tema yang digunakan dalam kegiatan bermain peran adalah tema Pekerjaan dan Binatang.

\section{a. Perencanaan}

Peneliti dan kolaborator bersama-sama menyiapkan Rencana Pelaksanaan Pembelajaran Harian (RPPH), kemudian menentukan langkahlangkah kegiatan untuk setiap kali pertemuan/tindakan serta mensetting lokasi kegiatan dan menyiapkan media pembelajaran atau alat permainan edukatif kegiatan bermain peran yang akan dimainkan. Adapun jadwal kegiatan bermain peran disusun berdasarkan kesepakatan bersama antara guru, kepala sekolah dan peneliti.

\section{b. Pelaksanaan dan Pengamatan}

Dalam tahapan pelaksanaan tindakan siklus I, guru dan peneliti melakukan pembelajaran melalui kegiatan bermain peran yang terdiri dari empat kali kegiatan bermain peran. Pertemuan I diawali dengan tema "Pekerjaan" dan sub tema "Bidang Pendidikan" serta sub subtema "Menjadi Guru". Kegiatan bermain peran yang dilakukan pada pertemuan II yaitu dengan tema "Pekerjaan" dan sub tema "Bidang Kesehatan, Sub-sub tema "Dokter". Kegiatan bermain peran yang dilakukan pada pertemuan III yaitu dengan tema "Pekerjaan" dan sub tema "Koki, Sub-sub tema "Menjadi koki cilik". Kegiatan bermain peran yang dilakukan pada pertemuan IV yaitu dengan tema "Pekerjaan" dan sub tema "Bidang Perikanan", sub-sub tema "Menjadi Nelayan". Pengamatan dilakukan oleh peneliti bersama kolaborator yaitu guru kelompok B PAUD Titian Kasih, Ternate-Maluku Utara. Berikut ini hasil pengamatan peneliti dari instrumen pemantau tindakan mengenai aktivitas guru dan anak. 
Tabel 3. Hasil Pengamatan Berdasarkan Instrumen Pemantau Tindakan Pada Siklus I

\begin{tabular}{|c|c|c|c|c|c|c|}
\hline \multirow[t]{2}{*}{ No. } & \multirow[t]{2}{*}{ Aktifitas Guru } & \multicolumn{2}{|c|}{$\begin{array}{c}\text { Hasil } \\
\text { Pengamatan }\end{array}$} & \multirow[t]{2}{*}{ Aktivitas Anak } & \multicolumn{2}{|c|}{$\begin{array}{c}\text { Hasil } \\
\text { Pengamatan }\end{array}$} \\
\hline & & Ya & Tidak & & Ya & Tidak \\
\hline 1. & $\begin{array}{l}\text { Guru menyiapkan alat dan } \\
\text { bahan yang akan digunakan } \\
\text { serta mengkondisikan kelas }\end{array}$ & $\sqrt{ }$ & & Anak siap mengikuti kegiatan & $\sqrt{ }$ & \\
\hline 2. & $\begin{array}{l}\text { Guru menjelaskan kegiatan } \\
\text { yang akan dilakukan }\end{array}$ & $\sqrt{ }$ & & $\begin{array}{l}\text { Anak mendengarkan } \\
\text { penjelasan guru dengan baik }\end{array}$ & $\sqrt{ }$ & \\
\hline 3. & $\begin{array}{l}\text { Guru memberikan anak } \\
\text { contoh untuk melakukan } \\
\text { kegiatan }\end{array}$ & $\sqrt{ }$ & & $\begin{array}{l}\text { Anak memperhatikan guru } \\
\text { dengan seksama }\end{array}$ & $\sqrt{ }$ & \\
\hline 4. & $\begin{array}{l}\text { Guru mempersilahkan anak } \\
\text { untuk melakukan kegiatan } \\
\text { bermain peran bersama }\end{array}$ & $\sqrt{ }$ & & $\begin{array}{l}\text { Anak mencoba melakukan } \\
\text { kegiatan bermain peran } \\
\text { bersama dengan antusias dan } \\
\text { perasaan senang }\end{array}$ & $\sqrt{ }$ & \\
\hline 5. & $\begin{array}{l}\text { Guru me-review kegiatan } \\
\text { yang telah dilakukan }\end{array}$ & $\sqrt{ }$ & & $\begin{array}{l}\text { Anak dapat menjawab } \\
\text { pertanyaan yang guru berikan } \\
\text { terkait dengan kegiatan } \\
\text { bermain peran yang telah } \\
\text { dilakukan }\end{array}$ & $\sqrt{ }$ & \\
\hline
\end{tabular}

\section{c. Refleksi}

Setelah hasil observasi didapatkan, maka kendala yang ditemui dalam pelaksanaan siklus I yaitu:

1) Anak cenderung memilih peran yang sama sehingga ada beberapa peran yang harus disiasati oleh guru. Pada siklus II menggunakan langkah awal yaitu dengan didatangkan narasumber untuk bercerita atau menggambarkan cerita atau peran yang akan dimainkan.

2) Pada pertemuan pertama sampai dengan pertemuan ke tiga masih ada beberapa anak yang belum mau mengikuti kegiatan bermain peran ini, dikarenakan motivasi dari guru yang masih kurang.

3) Masih ada beberapa anak yang masih diam saja ketika diminta untuk melakukan aktivitas bermain peran bersama. Guru dan peneliti menyiasati hal tersebut dengan membuat alat permainan edukatif yang lebih menarik perhatian anak.

\section{Deskripsi Data Siklus II}

\section{a. Perencanaan}

Peneliti melakukan penelitian dengan perencanaa tindakan pada siklus II peneliti dan kolaborator (guru kelompok B) dengan menekankan pada pemberian metode bermain peran mikro, menyiapkan rencana pelaksanaan pembelajaran harian dan merancang tindakan yang akan diberikan kepada 
anak, serta menyiapkan alat permainan edukatif yang digunakan dalam kegiatan bermain peran yang akan digunakan.

\section{b. Pelaksanaan dan Pengamatan}

Adapun kegiatan bermain peran mikro yang disajikan dalam siklus II adalah bermain peran menjadi nelayan, bermain peran perahu-perahuan, bermain peran mobil-mobilan, dan bermain peran menjadi sopir.

\section{Tabel 4. Hasil Pengamatan Berdasarkan Instrumen}

Pemantau Tindakan Pada Siklus II

\begin{tabular}{|c|c|c|c|c|c|c|}
\hline \multirow[t]{2}{*}{ No. } & \multirow[t]{2}{*}{ Aktifitas Guru } & \multicolumn{2}{|c|}{$\begin{array}{c}\text { Hasil } \\
\text { Pengamatan }\end{array}$} & \multirow[t]{2}{*}{ Aktivitas Anak } & \multicolumn{2}{|c|}{$\begin{array}{c}\text { Hasil } \\
\text { Pengamatan }\end{array}$} \\
\hline & & Ya & Tidak & & Ya & Tidak \\
\hline 1. & $\begin{array}{l}\text { Guru menyiapkan alat dan } \\
\text { bahan yang akan digunakan } \\
\text { serta mengkondisikan kelas }\end{array}$ & $\sqrt{ }$ & & Anak siap mengikuti kegiatan & $\sqrt{ }$ & \\
\hline 2. & $\begin{array}{l}\text { Guru menjelaskan kegiatan } \\
\text { yang akan dilakukan }\end{array}$ & $\sqrt{ }$ & & $\begin{array}{l}\text { Anak mendengarkan penjelasan } \\
\text { guru dengan baik }\end{array}$ & $\sqrt{ }$ & \\
\hline 3. & $\begin{array}{lrr}\text { Guru } & \text { memberikan anak } \\
\text { contoh } & \text { untuk melakukan } \\
\text { kegiatan } & & \\
\end{array}$ & $\sqrt{ }$ & & $\begin{array}{l}\text { Anak memperhatikan guru } \\
\text { dengan seksama }\end{array}$ & $\sqrt{ }$ & \\
\hline 4. & $\begin{array}{l}\text { Guru mempersilahkan anak } \\
\text { untuk mencoba melakukan } \\
\text { kegiatan bermain peran }\end{array}$ & $\sqrt{ }$ & & $\begin{array}{l}\text { Anak mencoba melakukan } \\
\text { kegiatan bermain peran dengan } \\
\text { antusias dan perasaan senang }\end{array}$ & $\sqrt{ }$ & \\
\hline 5. & $\begin{array}{l}\text { Guru me-review kegiatan yang } \\
\text { telah digunakan }\end{array}$ & $\sqrt{ }$ & & $\begin{array}{l}\text { Anak dapat menjawab } \\
\text { pertanyaan yang guru berikan } \\
\text { terkait dengan kegiatan yang } \\
\text { telah dilakukan }\end{array}$ & $\sqrt{ }$ & \\
\hline
\end{tabular}

\section{c. Refleksi}

Hasil refleksi pada siklus II menunjukkan anak sudah memiliki kecerdasan interpersonal dan kecerdasan intrapersonal dengan mengikuti setiap kegiatan bermain peran bersama. Berdasarkan hasil pengamatan selama siklus II berlangsung, dapat dianalisis sebagai berikut:

1) Sebelum jam pelajaran dimulai, beberapa anak mulai mendekat dan ikut mengambil beberapa alat dan bahan bermain untuk dibawa ke dalam kelas. Selain itu, guru memberikan rangsangan kepada anak dengan minta bantuan anak untuk mengambil alat dan bahan yang dibutuhkan. Hal ini menunjukkan anak sudah memiliki kecerdasan interpersonal yaitu memahami orang lain untuk melakukan kegiatan.

2) Saat kegiatan bermain peran berlangsung, tidak lagi terlihat anak yang pasif. Semua anak ikut terlibat dalam kegiatan bermain peran dan mulai menunjukkan keberanian dalam bekerja sama dengan orang lain. 
3) Pada saat guru melakukan tanya jawab terkait dengan cita-cita, anak sudah mampu mengungkapkan cita-cita sesuai dengan peran-peran yang anak mainkan dalam kegiatan bermain peran.

4) Berdasarkan catatan wawancara guru dan beberapa anak, mereka mengatakan bahwa kegiatan ini menyenangkan dan tidak membosankan sehingga bisa efektif untuk meningkatkan kecerdasan interpersonal dan kecerdasan intrapersonal.

5) Pada umumnya hasil prosentase anak yang pada siklus I belum mencapai skor $>70 \%$ pada kedua kecerdasan, pada siklus II beberapa anak tersebut sudah mencapai skor diatas $70 \%$. Sedangkan rata-rata kelas sudah mencapai 70,15\% untuk kecerdasan interpersonal dan 77,70\% pada kecerdasan intrapersonal sehingga siklus II ini dikatakan berhasil.

\section{Analisis Data}

Hasil perhitungan data peningkatan kecerdasan interpersonal dan kecerdasan intrapersonal disajikan ke dalam bentuk gambar grafik di bawah ini:

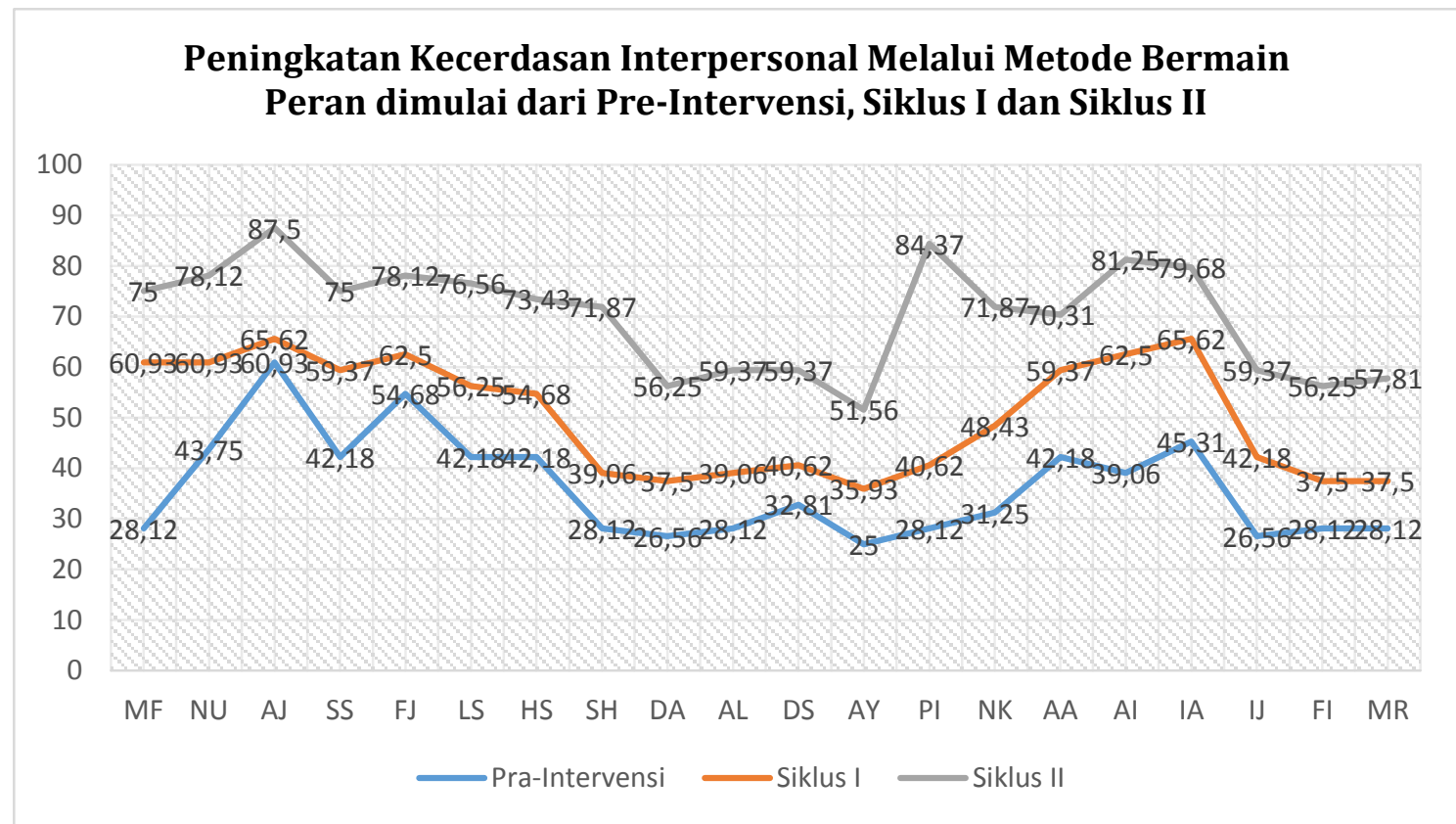

\section{Grafik Peningkatan Kecerdasan Interpersonal Melalui Metode Bermain Peran dimulai dari Pre-Intervensi, Siklus I dan Siklus II}

Berdasarkan grafik peningkatan hasil perkembangan kecerdasan interpersonal di atas, dapat dilihat peningkatan kecerdasan interpersonal anak mulai dari pra-intervensi, siklus I dan siklus II. Kecerdasan interpersonal anak pada kelompok B PAUD Titian Kasih, Ternate-Maluku Utara yang berjumlah 20 
anak dapat dilihat dari pra-intervensi dengan rata-rata hasil kecerdasan interpersonal sebesar 36,17\% mengalami peningkatan kecerdasan interpersonal pada siklus I sebesar 14,14 \% mencapai 50,31 \%. Selanjutnya, dari siklus I ke siklus II peningkatan kecerdasan interpersonal mengalami peningkatan sebesar 19,84 \% menjadi 70,15 \%. Hasil perhitungan data peningkatan kecerdasan intrapersonal disajikan ke dalam bentuk gambar grafik di bawah ini:

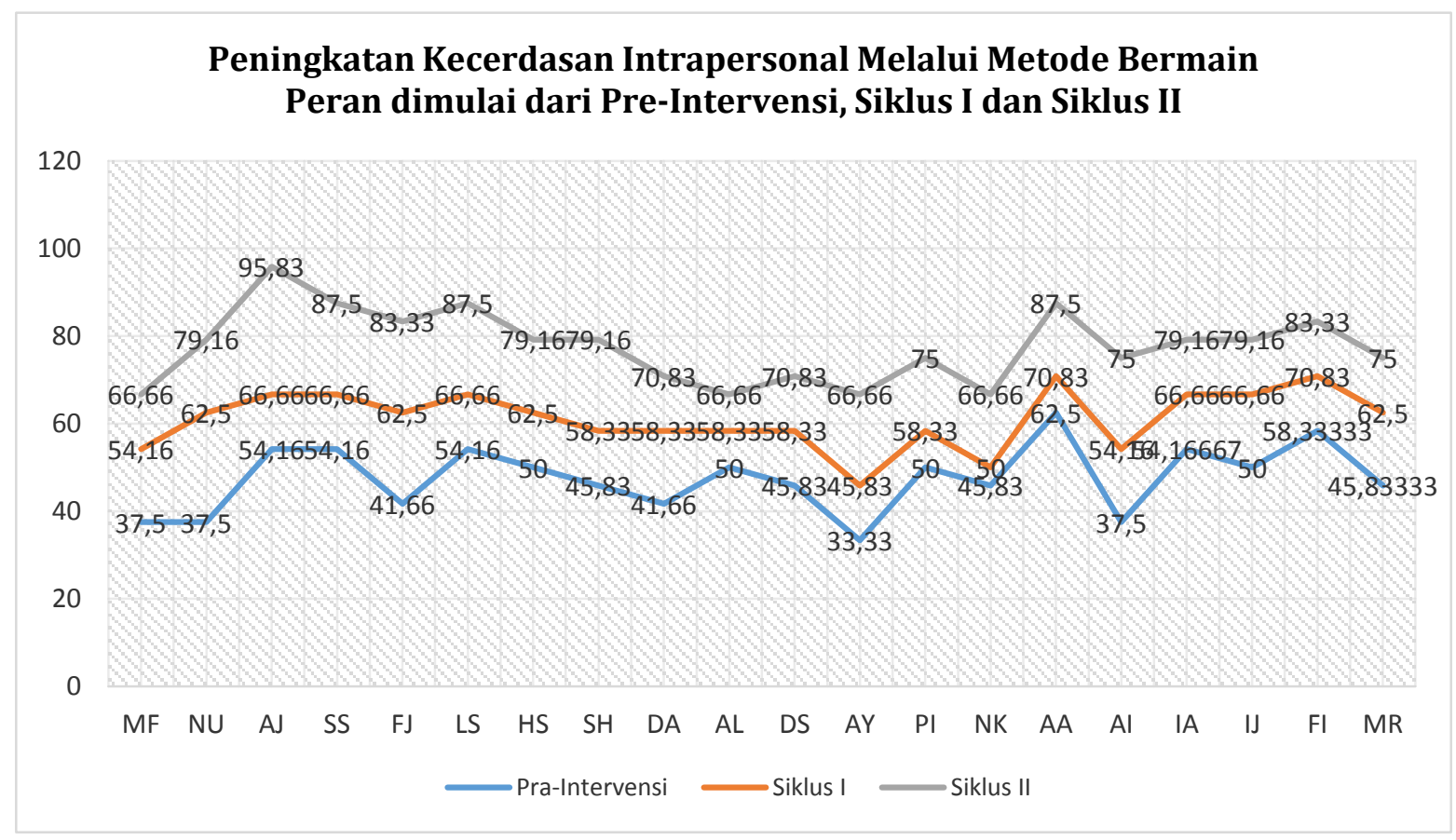

\section{Grafik Peningkatan Kecerdasan Intrapersonal Melalui Metode Bermain Peran dimulai dari Pre-Intervensi, Siklus I dan Siklus II}

Berdasarkan grafik peningkatan hasil perkembangan kecerdasan intrapersonal di atas, dapat dilihat peningkatan kecerdasan intrapersonal anak mulai dari pra-intervensi, siklus I dan siklus II. Kecerdasan intrapersonal anak pada kelompok B PAUD Titian Kasih, Ternate-Maluku Utara yang berjumlah 20 anak dapat dilihat dari pra-intervensi dengan rata-rata hasil kecerdasan intrapersonal sebesar 47,5\% mengalami peningkatan kecerdasan intrapersonal pada siklus I sebesar 12,70\% mencapai 60,20\%. Selanjutnya, dari siklus I ke siklus II peningkatan kecerdasan intrapersonal mengalami peningkatan sebesar $17,5 \%$ menjadi $77,70 \%$.

Selain melihat peningkatan kecerdasan intrapersonal anak secara keseluruhan, peneliti juga melihat peningkatan yang dialami anak pada masingmasing aspek, yaitu mengenal diri sendiri, menerima kritikan dan memiliki citacita yang jelas. Dengan melihat peningkatan pada masing-masing aspek akan 
memudahkan untuk mengidentifikasi perbaikan tindakan pada siklus berikutnya. Dari seluruh data yang ada peningkatan dari pra-intervensi sampai pada siklus II sudah mencapai lebih dari target yang sudah ditentukan yaitu 70,15\% dan 77,70\% melalui kegiatan bermain peran.

\section{Simpulan}

Kecerdasan interpersonal dan kecerdasan intrapersonal dapat ditingkatkan melalui metode bermain peran. Hal ini dapat dilihat dari adanya kenaikan rerata skor kecerdasan interpersonal dan kecerdasan intrapersonal anak setelah diterapkan metode bermain peran melalui 2 siklus. Berdasarkan data hasil pengamatan tindakan yang dilakukan terhadap 12 responden pada akhir siklus I, dimana kecerdasan interpersonal dan kecerdasan intrapersonal anak mengalami peningkatan sebesar 10,37\%, pada pra test diperoleh rata-rata kelas sebesar 41,33 atau 46,96\% dan pada siklus I menjadi 46 atau 57,33\%. Pada siklus II kecerdasan interpersonal dan kecerdasan intrapersonal anak semakin mengalami peningkatan sebesar 22,59\%, dimana pada siklus II anak memperoleh rata-rata skor 64,47 atau 79,92\%. Maka pada akhir siklus II penelitian dikatakan berhasil karena prosentase kenaikan lebih dari keriteria keberhasilan yang disepakati oleh peneliti dan kolaborator.

Pelaksanaan Metode bermain peran dalam proses belajar mengajar memberikan anak kesempatan untuk menggali berbagai kecerdasan yang dimiliki oleh anak, khususnya kecerdasan kecerdasan interpersonal dan kecerdasan intrapersonal.

\section{Daftar Rujukan}

Arikunto, Suharsimi. (2006). Prosedur Penelitian Suatu Pendekatan Praktik. Jakarta: Rineka Cipta.

Armstrong Thomas. (2009). Multiple Intelligences in the Classroom. USA Virginia Alexandria: Association for Supervision and Curriculum Development.

Hoerr, R. Thomas. (2007). Buku Kerja Multiple Intelligences. Bandung: Mizan Pustaka.

Musfiroh, Tadkiroatun. (2008). Cerdas Melalui Bermain, Cara Mengasah Multiple Intelligence. Jakarta: Grasindo.

Nurunnisa, Euis C. (2017). Melek Kecerdasan Interpersonal Anak Usia Dini. Jurnal:Tunas Siliwangi Volume 2 Nomor 2 Oktober 2017.

Suyadi. (2014). Teori Pembelajaran Anak Usia Dini Dalam Kajian Neurosains. Bandung: Remaja Rosdakarya. 2014 